Luiz Alberto Barcelos Marinho'

José Guilherme Cecatti'

Maria José Duarte Osis"

Maria Salete Costa Gurgel'
Departamento de Tocoginecologia. Faculdade de Ciências Médicas. Universidade Estadual de Campinas. Campinas, SP, Brasil

" Centro de Pesquisas em Saúde Reprodutiva de Campinas. Campinas, SP, Brasil

\section{Knowledge, attitude and practice of mammography among women users of public health services}

\author{
Conhecimento, atitude e prática \\ da mamografia entre usuárias do \\ serviço público de saúde
}

\section{ABSTRACT}

OBJECTIVE: To evaluate knowledge, attitude and practice related to mammography among women users of local health services, identifying barriers to its performance.

METHODS: A total of 663 women were interviewed at 13 local health centers in a city of Southeastern Brazil, in 2001. Interviewees were randomly selected at each center and they were representative from different socioeconomic conditions. The number of interviewees at each center was proportional to monthly mean appointments. For data analysis, answers were described as knowledge, attitude, practice and their respective adequacies and then they were correlated with control variables through the chi-square test.

RESULTS: Only $7.4 \%$ of the interviewees had adequate knowledge on mammography, while $97.1 \%$ of women had an adequate attitude. The same was seen for the practice of mammography that was adequate in $35.7 \%$ of the cases. The main barrier to mammography was lack of referral by physicians working at the health center (81.8\%). There was an association between adequacy of attitude and five years or more of education and being married. There was also an association between adequacy of mammography practice and being employed and family income up to four minimum wages.

CONCLUSIONS: Women users of local health services had no adequate knowledge and practice related to mammography despite having an adequate attitude about this exam.

DESCRIPTORS: Mammography. Health Knowledge, Attitudes, Practice. Breast Neoplasms, prevention \& control. Women's Health Services. Women's Health. 


\section{RESUMO}

OBJETIVO: Avaliar o conhecimento, a atitude e a prática do exame de mamografia entre as mulheres usuárias do serviço médico municipal, identificando as barreiras para seu acesso à realização do procedimento.

MÉTODOS: Foram entrevistadas 663 mulheres de 13 centros de saúde municipais de Campinas, SP, em 2001. As entrevistadas foram incluídas de forma aleatória, representando diferentes estratos sociais. O número de entrevistas em cada centro de saúde foi proporcional ao número médio mensal de mulheres atendidas. As respostas foram descritas quanto ao conhecimento, atitude e prática e suas respectivas adequações. A adequação foi correlacionada com variáveis de controle utilizando o teste qui-quadrado.

RESULTADOS: Apenas 7,4\% das entrevistadas tinham conhecimento adequado sobre o exame de mamografia, embora a atitude frente a este procedimento tenha sido adequada em $97,1 \%$ das mulheres e a prática adequada em $35,7 \%$ das entrevistadas. A principal barreira para a realização da mamografia foi a não solicitação por parte dos médicos dos centros de saúde (81,8\%). A adequação da atitude esteve relacionada à escolaridade igual ou superior a cinco anos e ser casada. A prática adequada da mamografia associou-se com o trabalho fora de casa e renda familiar igual ou superior a cinco salários mínimos.

CONCLUSÕES: O conhecimento e a prática da mamografia entre as usuárias do serviço médico municipal foi inadequada, apesar da atitude adequada em relação ao procedimento.

\section{DESCRITORES: Mamografia. Conhecimentos, Atitudes e Prática em Saúde. Neoplasias Mamárias, prevenção \& controle. Serviços de Saúde da Mulher. Saúde da Mulher.}

\section{INTRODUCTION}

Breast cancer is the second most common neoplasia and the first leading cause of cancer death among Brazilian women. There were 48,930 new cases in Brazil in 2006, a standardized incidence rate of 52 per 100,000 women. $^{\mathrm{a}}$

Primary randomized controlled trials (RCT) have showed the importance of mammography for early diagnosis of breast cancer in asymptomatic women. It has been the most efficient resource for decreasing disease mortality, especially in women aged 50 to 69 years, ${ }^{6,12,19,22}$ with reductions of $20 \%$ to $35 \%$. However, breast cancer screening in community practices may be different from that in RCT. ${ }^{6}$

Mammography high cost prevents large-scale screening in many countries. ${ }^{3}$ Studies showed that low-income women have also more difficult access to mammography. ${ }^{1,8}$ Besides the economic issue, there are other difficulties: fear of irradiation, obstacles of public services, ${ }^{15,17}$ and pain, discomfort, and anxiety about the screening. ${ }^{6}$

First difficulties to screening mammography should be identified and then community health care authorities should establish strategies to overcome them. It is essential to have comprehensive knowledge, attitude and practice of mammography in the target population, stressing the importance of implementing it as a routine and preventive measure for early diagnosis of breast cancer.

The objective of the present study was to evaluate knowledge, attitude and practice of women towards mammography and to identifying potential barriers to screening among women users of health centers.

a Ministério da Saúde. Instituto Nacional de Câncer. Estimativa 2006: Incidência de câncer no Brasil. Rio de Janeiro; 2006 [accessed on 4/10/2007] Available from: http://www.inca.gov.br/estimativa/2006/versaofinal.pdf 


\section{METHODS}

Descriptive, observational study of knowledge, attitude and practice (KAP) $)^{24}$ carried out in 13 municipal health centers in Campinas, Southeastern Brazil. A total of 663 women attending medical visits at internal medicine, gynecology and nursing care units were interviewed between August 2000 and March 2001. Health centers were randomly selected from the 43 existing in the city and users were representative from different socioeconomic conditions. A questionnaire previously tested in other units was used to evaluate KAP on mammography and to identify barriers to screening.

Health centers were selected according to socioeconomic conditions (better-off and deprived areas) taking into account the number of public schools in the corresponding area and whether or not there was a water supply system. A random stratification process was used to select 13 health centers including a wide range of socioeconomic characteristics.

The sample size was based on the average number of women assisted in the first semester of 1998 and a stratified random sampling described by Scheaffer et al. ${ }^{21}$ The estimated sample size was 663 women, corresponding to a sample fraction of about $1.1 \%$, proportional to care flow at each health center.

Women aged 40 and older enrolled in the health center for at least six months were included in the study. Those with a personal history of breast cancer or who had other medical insurance were excluded. Interviews were performed by previously trained nursing assistant staff from the same health centers while women waited for their appointment at internal medicine, gynecology or nursing care units. One in every five women meeting the inclusion criteria was asked to participate in the study. When a woman refused to be interviewed, the next one was asked, and so forth. Refusal rate to participate was very low.

Adequate knowledge on mammography was defined when interviewees provided correct statements about the availability and use of the exam and how it is practiced. Examples of questions and correct answers were as follows: "Have you heard anything about an exam called mammography?" "When have you first heard about mammography? During educational activities at the health center? On the radio or television? In conversations with friends or neighbors?” If women considered correct the following statement: "It's $a$ special X-ray to detect lumps in your breasts / It's a procedure to detect any problem in your breasts / It's an important procedure that should be carried out along with clinical and breast self-examination."

Women's attitude towards mammography was considered appropriate when they expressed a favorable opinion and consistently supported it. Some examples of questions and correct answers were: "How necessary do you think a mammography is? Very necessary? Fairly necessary? Not necessary? Why?" "I think this exam is very necessary because: It's the best one to detect breast conditions. / This exam can detect early breast cancer. Sometimes the diagnosis of breast cancer comes late."

The practice of mammography was considered adequate when women reported undergoing it following medical prescription or their own will and when the time interval between two mammography exams was not greater than two years. As for those subjects who had not had mammography, the main reason given for that was analyzed.

The questionnaires were reviewed for information quality and legitimacy, and corrections were made as needed. The data were through cleanliness and consistency tests and variable frequency analysis and entered into EpiInfo 6.1 program. Associations between sociodemographic characteristics (age, education, paid job, marital status, family income and length of time being assisted at the health center) and adequacy of KAP of mammography was evaluated according to the interviewees' answers using a two-sided chi-square test, with a $5 \%$ significance level.

Correct and consistent answers, regarding the value of mammography was considered adequate knowledge. An attitude was considered adequate when interviewees were positive on the value of mammography and supported their answer with statements that imparted consistency to their previous answer. Practice was considered adequate when interviewees correctly answered the questions regarding the method and desired frequency of mammography.

The study was approved by the institution's Research Ethics Committee and followed the principles of the Declaration of Helsinki.

\section{RESULTS}

Most interviewees were over 50 years of age (67.9\%), had lower education (80.6\%), no active participation in the labor market $(70.1 \%)$ and low family income up to four minimum wages (67.1\%). More than half of the interviewees reported four pregnancies or more (56.1\%) and over $80 \%$ had attended the health center for more than two years (Table 1).

Users showed knowledge about mammography (93.5\%) and their health centers were the main instrument to promote this knowledge (56.0\%). Nevertheless, few interviewees (7.4\%) had adequate knowledge about mammography. Similarly, they showed a positive attitude towards mammography and most had an adequate attitude (97.1\%) (Table 2). 
Table 1. Distribution of women users of local health services according to sociodemographic characteristics. Campinas, Southeastern Brazil, 2000-2001. ( $N=663)$

\begin{tabular}{|c|c|c|}
\hline Characteristic & $\mathrm{N}$ & $\%$ \\
\hline \multicolumn{3}{|l|}{ Age (years) } \\
\hline $40-44$ & 137 & 20.7 \\
\hline $45-50$ & 142 & 21.4 \\
\hline$>50$ & 384 & 57.9 \\
\hline \multicolumn{3}{|l|}{ Schooling (years)* } \\
\hline None & 116 & 17.7 \\
\hline $1-4$ & 412 & 62.9 \\
\hline $5-8$ & 97 & 14.8 \\
\hline $9-11$ & 15 & 2.3 \\
\hline$\geq 12$ & 15 & 2.3 \\
\hline \multicolumn{3}{|l|}{ Paid job } \\
\hline Yes & 198 & 29.9 \\
\hline No & 465 & 70.1 \\
\hline \multicolumn{3}{|l|}{ Marital status } \\
\hline Married & 396 & 59.7 \\
\hline Single & 42 & 6.3 \\
\hline Widow & 123 & 18.6 \\
\hline Living with a partner & 37 & 5.6 \\
\hline Divorced & 65 & 9.8 \\
\hline \multicolumn{3}{|c|}{ Family income (minimum wages) ${ }^{* *}$} \\
\hline 1 & 131 & 22.2 \\
\hline $2-4$ & 265 & 44.9 \\
\hline $5-9$ & 155 & 26.3 \\
\hline$\geq 10$ & 39 & 6.6 \\
\hline \multicolumn{3}{|l|}{ Number of pregnancies } \\
\hline None & 23 & 3.5 \\
\hline 1 & 44 & 6.6 \\
\hline 2 & 97 & 14.6 \\
\hline 3 & 127 & 19.2 \\
\hline$\geq 4$ & 372 & 56.1 \\
\hline \multicolumn{3}{|c|}{ Time attending health centers (months) } \\
\hline $6-12$ & 59 & 8.9 \\
\hline $13-24$ & 58 & 8.7 \\
\hline $25-60$ & 182 & 27.5 \\
\hline $61-120$ & 151 & 22.8 \\
\hline$>120$ & 213 & 32.1 \\
\hline \multicolumn{3}{|c|}{ Family history of breast cancer } \\
\hline Yes & 60 & 9.0 \\
\hline No & 603 & 91.0 \\
\hline
\end{tabular}

* Missing information on 8 women

** Missing information on 73 women

Half of the women seeking medical care at the health centers reported they had not been referred to mammography (50.7\%). Among those who had had mammography exams, their main indication was age (Table 3).
Table 2. Knowledge, its sources and adequacy, and attitude of women users of health services regarding screening mammography. Campinas, Southeastern Brazil, 2000-2001.

\begin{tabular}{lcc}
\hline Variable & $\mathrm{N}$ & $\%$ \\
\hline $\begin{array}{l}\text { Knowledge } \\
\quad \text { Yes }\end{array}$ & 620 & 93.5 \\
$\quad$ No & 43 & 6.5 \\
Source & & \\
$\quad$ Health center & 353 & 56.0 \\
$\quad$ Radio/TV & 105 & 16.9 \\
$\quad$ Workplace & 90 & 14.5 \\
$\quad$ Neighbors/friends & 16 & 2.6 \\
$\quad$ Churches & 36 & 5.8 \\
$\quad$ Schools & 2 & 0.3 \\
$\quad$ Does not remember & 7 & 1.1 \\
$\quad$ Other & 11 & 1.8 \\
Adequacy of knowledge & & \\
$\quad$ Adequate & & \\
Inadequate & 49 & 7.4 \\
Attitude** & 614 & 92.6 \\
Adequate (very necessary, & 602 & 97.1 \\
necessary) & & \\
Inadequate (not very \\
necessary, unnecessary)
\end{tabular}

* More than one answer per women

** Missing information on 43 women who did not have knowledge on screening mammography

Of those who were supposed to have a mammography every 24 months, only $38 \%$ underwent the exam and the adequacy rate was low (35.7\%). Among those who did not have the exam, no medical referral was the main barrier (81.8\%) (Table 4).

There was not found an association between sociodemographic variables and adequacy of knowledge. There was an association between adequate attitude and higher education and the status of being married as well as an association between adequate practice and having a paid job and family income higher than five minimum wages (Table 5).

\section{DISCUSSION}

Low education and socioeconomic conditions are major factors for diagnosis delay, response to treatment and survival rates in several cancers, including breast cancer. ${ }^{1,2,13,16}$ In the present study most women studied had a low educational level and low socioeconomic condition which certainly contributed to the study findings. Most interviewees had inadequate knowledge (92.6\%) and the health service was their main source of information (56\%). In a recent study in Goiania, 
Table 3. Distribution of women users of local health care centers according to mammography requested by the health center doctor, indication and other variables. Campinas, Southeastern Brazil, 2000-2001.

\begin{tabular}{|c|c|c|}
\hline Variable & $\mathrm{N}$ & $\%$ \\
\hline \multicolumn{3}{|l|}{ Doctor requested exam } \\
\hline Yes & 327 & 49.3 \\
\hline No & 336 & 50.7 \\
\hline \multicolumn{3}{|l|}{ Indication for mammography } \\
\hline Noticed a breast nodule & 23 & 9.1 \\
\hline $\begin{array}{l}\text { Noticed a breast nodule and was } \\
\text { examined by doctor }\end{array}$ & 1 & 0.4 \\
\hline $\begin{array}{l}\text { Noticed a breast nodule and was } \\
\text { not examined by doctor }\end{array}$ & 8 & 3.2 \\
\hline Afraid of breast cance & 8 & 3.2 \\
\hline \multicolumn{3}{|c|}{ Asked the doctor about the exam after a neighbor } \\
\hline had one and a nodule was found & 3 & 1.2 \\
\hline Age & 150 & 59.5 \\
\hline $\begin{array}{l}\text { Doctor was uncertain about asking } \\
\text { for the exam }\end{array}$ & 6 & 2.4 \\
\hline Cases of breast cancer in the family & 5 & 2.0 \\
\hline Papillary discharge & 2 & 0.8 \\
\hline Pain & 40 & 15.9 \\
\hline Does not know & 5 & 2.0 \\
\hline Other & 1 & 0.4 \\
\hline
\end{tabular}

Midwestern Brazil, including 531 women, television was reported as the main source of information about breast cancer (26.5\%). ${ }^{9}$

Although many of them had a favorable attitude towards mammography, in the present study only one-third of them (35.7\%) have had it routinely and adequately performed.

In a recent similar study conducted in 1,012 Chinese women from Hong Kong, 58\% had never heard of mammography screening. Lack of time and costs were the most frequently reported reasons for their reluctance to participate in clinical breast examinations or mammography screenings. ${ }^{4}$

For a successful fight against breast cancer it is necessary to promote a behavior change in both women and health professionals, especially those providing care to the poor and improve women's knowledge, attitude and practice regarding screening mammography.

Since the most famous study on mammography screening was published, mammography has been definitively incorporated into the early diagnosis of breast tumors. ${ }^{5,6,22,23}$

Although mammography and clinical breast examination are widely used in breast cancer screening, their
Table 4. Distribution of women users of local health care centers according to characteristics regarding the practice of mammography. Campinas, Southeastern Brazil, 20002001.

\begin{tabular}{lcc}
\hline Characteristic & $\mathrm{N}$ & $\%$ \\
\hline Mammography performed & & \\
$\quad$ Yes & 252 & 38.0 \\
No & 411 & 62.0 \\
Number of previous mammographies & & \\
$1-4$ & 235 & 93.2 \\
$5-8$ & 13 & 5.2 \\
$\geq 9$ & 4 & 1.6
\end{tabular}

Time elapsed since the last mammography (in months)

$\begin{array}{lcc}1-12 & 93 & 35.9 \\ 13-24 & 12 & 4.7 \\ \text { Does not remember } & 147 & 58.3\end{array}$

Time elapsed since the first mammography (in months)

$\begin{array}{lcc}6-24 & 144 & 57.2 \\ 25-60 & 76 & 30.1 \\ 61-120 & 28 & 11.2 \\ 121-240 & 4 & 1.6\end{array}$

Time interval between mammographies (in months)

$\begin{array}{lcc}6-24 & 237 & 94.3 \\ 25-36 & 12 & 4.4 \\ \geq 37 & 3 & 1.6\end{array}$

Practice of mammography considered adequate

$\begin{array}{lll}\text { Yes } & 237 & 35.7 \\ \text { No } & 426 & 64.2\end{array}$

Barriers to mammography

\begin{tabular}{lcc} 
Difficult access & 57 & 13.9 \\
Painful examination & 1 & 0.2 \\
Fear & 15 & 3.6 \\
Doctor did not request it & 336 & 81.8 \\
Lack of time & 2 & 0.5 \\
\hline
\end{tabular}

beneficial impact remains controversial. A systematic review of Cochrane Library reviewed the main RCTs on the practice of screening mammography developed in the past decades and the authors questioned some results of previous studies, mainly concerning randomization. They concluded there is not enough evidence to support that mammography screening reduces deaths rate of breast cancer. ${ }^{20}$ However, despite some biases found in these trials, other studies concluded they are not sufficiently relevant to invalidate the efficacy of mammography screening found in RCTs. ${ }^{6,12}$

But breast cancer screening in community health care may not be as effective as that suggested by RCTs, performed under ideal circumstances. There is a need to further explore the effects of current screening 
Table 5. Assessment of adequacy of knowledge, attitude and practice of mammography according to sociodemographic variables of women users of local health care centers. Campinas, Southeastern Brazil, 2000-2001.

\begin{tabular}{|c|c|c|c|c|}
\hline Variable & $\begin{array}{c}\text { Adequate } \\
\%\end{array}$ & $\begin{array}{c}\text { Inadequate } \\
\% \\
\end{array}$ & $X^{2}$ & $\mathrm{p}$-value \\
\hline \multicolumn{5}{|l|}{ Knowledge } \\
\hline Age $\geq 50$ years & 55 & 58 & 0.07 & NS \\
\hline Education $\geq 5$ years & 22 & 19 & 0.18 & NS \\
\hline Paid job & 41 & 29 & 2.49 & NS \\
\hline Married & 61 & 60 & 0.05 & NS \\
\hline Income $\geq 5$ minimum wages & 33 & 29 & 0.14 & NS \\
\hline Time attending health center & 94 & 91 & 0.23 & NS \\
\hline Total $(\mathrm{N})$ & 49 & 614 & & \\
\hline \multicolumn{5}{|l|}{ Attitude } \\
\hline Age $\geq 50$ years & 56 & 67 & 0.38 & NS \\
\hline Education $\geq 5$ years & 21 & 0 & 3.44 & 0.03 \\
\hline Paid job & 31 & 33 & 0.04 & NS \\
\hline Married & 61 & 33 & 4.34 & 0.03 \\
\hline Income $\geq 5$ minimum wages & 31 & 17 & 1.01 & NS \\
\hline Time attending health center & 90 & 94 & 0.02 & NS \\
\hline Total* $(\mathrm{N})$ & 602 & 18 & & \\
\hline \multicolumn{5}{|l|}{ Practice } \\
\hline Age $\geq 50$ years & 59 & 57 & 1.09 & NS \\
\hline Education $\geq 5$ years & 20 & 19 & 0.02 & NS \\
\hline Paid job & 37 & 25 & 4.58 & 0.03 \\
\hline Married & 87 & 56 & 1.30 & NS \\
\hline Income $\geq 5$ minimum wages & 39 & 24 & 9.76 & 0.001 \\
\hline Time attending health center & 98 & 87 & 0.41 & NS \\
\hline Total (N) & 237 & 426 & & \\
\hline
\end{tabular}

* Missing information for 43 women who did not have knowledge on screening mammography

NS: not significant

practices in the general population. ${ }^{11}$ A recent casecontrol study conducted in six health plans in the United States showed that screening history was not associated with reduced breast cancer mortality and suggested that mammography screening might be effective only among women who are at increased risk for breast cancer.?

A cost-effectiveness analysis in Switzerland compared a mammography screening program (MSP) with an opportunistic screening strategy (OS) based on clinical practice. ${ }^{18}$ This economic analysis showed incremental costs per life-year gained for MSP were about twice those found for OS and it was concluded that MSP enables a significant reduction of breast cancer mortality compared with OS.

Notwithstanding, investments are made to improving mammography techniques (especially digital mammography) or other forms of screening (magnetic resonance imaging) based on the belief of its actual benefit to women. ${ }^{6,14}$

In Brazil, the first official data on mammography utilization comes from a household survey by the Instituto Nacional do Câncer (INCA - Brazilian National Cancer Institute). It comprised 2,525 women aged 50 to 69 years between 2002 and 2003 in 15 capitals plus the Federal District. It showed that $54 \%$ of the women studied had a mammography in the prior two years, one third of them in public health services and the remaining in health insurance covered or private services. ${ }^{a}$

The data of the present study should be analyzed from two different aspects. First, there is a need for an ongoing program for early detection of breast cancer. Women

a Ministério da Saúde. Instituto Nacional de Câncer. Inquérito domiciliar sobre comportamento de risco e morbidade referida de doenças e agravos não transmissíveis. Rio de Janeiro; 2005 [accessed on: 5/20/2007]. Available from: http://dtr2004.saude.gov.br/nutricao/documentos/publicacao_inquerito22_06.pdf 
cannot rely on seasonal campaigns only, many of them aiming more at political interests than people's wellbeing. From this viewpoint, it is essential to provide accurate information focusing on disease prevention, such as breast cancer prevention, to both the target population and health professionals working directly with them. There is a need of resources to identify breast tumors, provide better training on clinical breast examination and practical procedures and improve referral of suspected cases.

The results of the present study are in agreement with another Brazilian study that found a similar proportion of no mammography referrals in both public and private health services ( $84.3 \%$ and $46 \%$, respectively). They also found that about $30 \%$ of women seen in public services did not undergo mammography because the health professionals considered it unnecessary. ${ }^{10}$ Apparently there is greater medical resistance than women's regarding mammography in asymptomatic patients.

The lack of programs for early detection of breast tumors - a responsibility of health authorities - ends up negatively affecting patients who have their chances of cure reduced, experience greater mutilation and cause more suffering during treatment and to their family. In addition, there are further losses to the public sector with increased costs to treat cases that could have been early diagnosed. The implementation of an educational program targeting women's health and more specifically focusing on early diagnosis of breast cancer is the only action that could change the current situation.

Unfortunately, due to operational issues, this study could not be extended to all health centers in the city of Campinas, which would have allowed to gathering data that would either ratify or rectify the results obtained in the present study. It is suggested further investigation of health insured women. Combined to the data of the present study, both could provide better understanding of the barriers faced by women when trying to gain access to a procedure of greater complexity such as mammography.

In conclusion, users of local health services in Campinas had inadequate knowledge and practice concerning screening mammography, although they show an adequate attitude towards the exam. The main barrier to mammography is related to the public health system: patients did not undergo the exam because they were not referred by their doctors. 


\section{REFERENCES}

1. Blanchard K, Colbert JA, Puri D, Weissman J, Moy B, Kopans DB, et al. Mammographic screening: patterns of use and estimated impact on breast carcinoma survival. Cancer. 2004;101(3):495-507.

2. Cella DF, Orav EJ, Kornblith AB, Holland JC, Silberfarb PM, Lee KW, et al. Socioeconomic status and cancer survival. J Clin Oncol. 1991;9(8):1500-9.

3. Chen SL, Clark S, Pierce LJ, Hayes DF, Helvie MA, Greeno PL, et al. An academic health center cost analysis of screening mammography. Cancer. 2004;101(5):1043-50.

4. Chua MST, Mok TS, Kwan WH, Yeo W, Zee B. Knowledge, perceptions, and attitudes of Hong Kong Chinese women on screening mammography and early breast cancer management. Breast J. 2005;11(1):52-6.

5. Duffy SW, Tabár L, Chen HH, Holmqvist M, Yen MF, Abdsalah S, et al. The impact of organized mammography service screening on breast carcinoma mortality in seven Swedish counties. Cancer. 2002;95(3):458-69.

6. Elmore JG, Armstrong K, Lehman CD, Fletcher SW. Screening for breast cancer. JAMA. 2005;293(10):1245-56.

7. Elmore JG, Reisch LM, Barton MB, Barlow WE, Rolnick $\mathrm{S}$, Harris EL, et al. Efficacy of breast cancer screening in the community according to risk level. I Natl Cancer Inst. 2005;97(14):1035-43.

8. Freeman HP, Wasfie TJ. Cancer of the breast in poor black women. Cancer. 1989;63(12):2562-9.

9. Godinho ER, Koch HA. O perfil da mulher que se submete a mamografia em Goiânia - Uma contribuição a "Bases para um programa de detecção precoce do câncer de mama". Radiol Bras. 2002;35(3):139-45.

10. Godinho ER, Koch HA. Fontes utilizadas pelas mulheres para aquisição de conhecimentos sobre câncer de mama. Radiol Bras. 2005;38(3):169-73.

11. Harris R. Effectiveness: the next question for breast cancer screening. J Natl Cancer Inst. 2005;97(14):1021-3.

12. Humphrey LL, Helfand M, Chang BK, Woolf SH. Breast cancer screening: a summary of the evidence for the US Preventive Services Task Force. Ann Intern Med. 2002;137(5 Part 1):347-60.
13. Jiminez-Lee R, Oslak SG, Hedberg K, Vetto JT. Surgical outcomes of breast cancer screening program for lowincome women. Arch Surg. 2003;138(8):884-90.

14. Koomen M, Pisano ED, Kuzmiak C, Pavic D, McLelland R. Future directions in breast imaging. J Clin Oncol. 2005;23(8):1674-7.

15. Lerman C, Rimer B, Trock B, Balshem A, Engstrom PF. Factors associated with repeat adherence to breast cancer screening. Prev Med. 1990;19(3):279-90.

16. McWhorter WP, Schatzkin AG, Horm JW, Brown CC. Contribution of socioeconomic status to black/ white differences in cancer incidence. Cancer. 1989;63(5):982-7.

17. Miller MA, Champion VL. Attitudes about breast cancer and mammography - racial, income and educational differences. Women Health. 1997;26(1):41-63.

18. Neeser K, Szucs T, Bulliard JL, Bachmann G, Schramm W. Cost-effectiveness analysis of a quality-controlled mammography screening program from the Swiss Statutory Health-care perspective: quantitative assessment of the most influential factors. Value Health. 2007;10(1):42-53.

19. Nyström L, Andersson I, Bjurstam N, Frisell J, Nordenskjöld B, Rutqvist LE. Long-term effects of mammography screening: updated overview of the Swedish randomized trials. Lancet. 2002;359(9310):909-19.

20. Olsen O, Gøtzsche PC. Screening for breast cancer with mammography. Cochrane Database Syst Rev. $2001 ;(4)$ :CD001877.

21. Scheaffer RL, Mendenhall W, Ott L. Elementary survey sampling. 3. ed. Boston: Duxbury Press; 1986.

22. Shapiro S, Strax P, Venet L. Periodic breast screening in reducing mortality from breast cancer. JAMA. 1971;215(11):1777-85.

23. Tábar LK, Vitak B, Chen HH, Yen MF, Duffy SW, Smith RA. Beyond randomized controlled trials: organized mammographic screening substantially reduces breast cancer mortality. Cancer. 2001;91(9):1724-31.

24. Warwick DP, Lininger AC. The sample survey: theory and practice. New York: McGraw Hill; 1975. 